\title{
SNAPSHOT
}

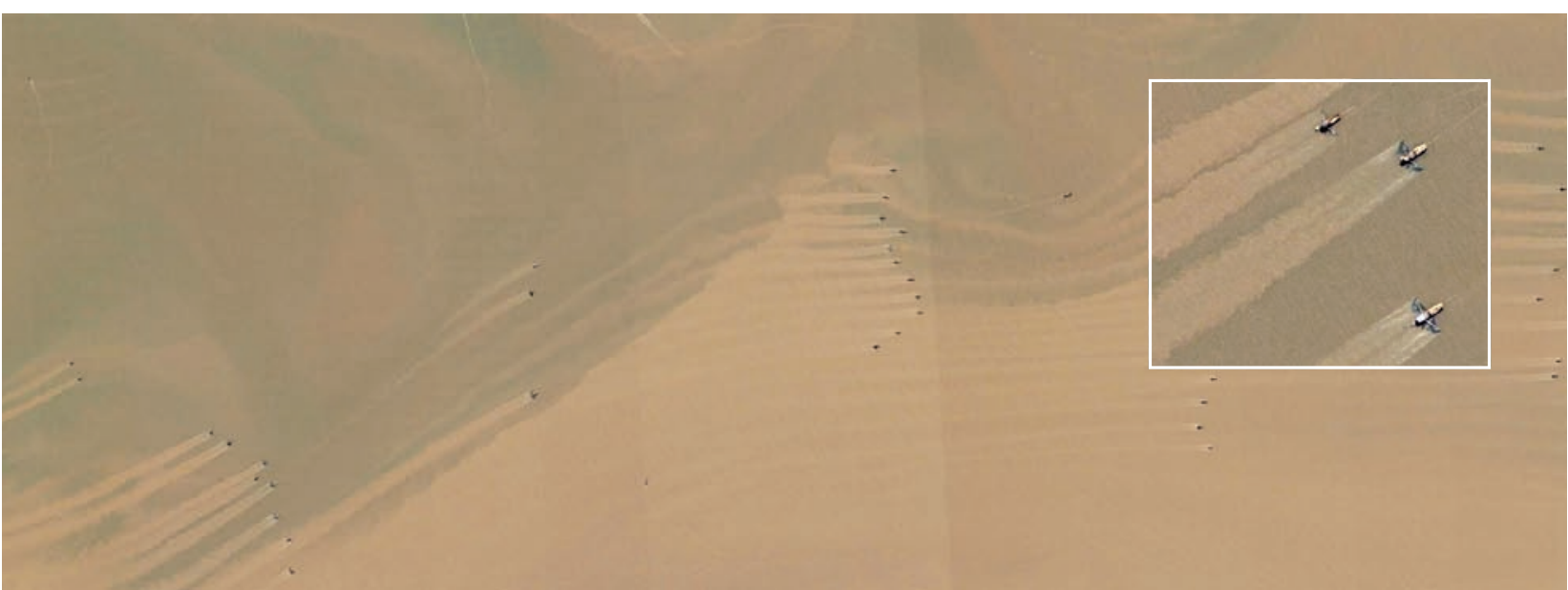

\section{Ghosts of destruction}

\section{破壊の幻影}

Nature Vol.447(123)/10 May 2007

編隊を組んで飛ぶジェット機の飛行機 雲? 枯山水の禅庭の砂に熊手で描かれ た規則正しい文様? それとも、大草原 を並んで進む刚り取り機の集団?

いや、これは中国の沿岸でエビ漁を するトロール漁船群を捕らえた画像であ る(右の枠內に拡大像)。これらの長い 「泥の航跡」は、エビ漁の網によって堆 積物がかき混ぜられてできたもので、 漁船が通った跡に海底生態系が擋乱さ れていることがはっきりと見てとれる。
保全生態学者であるデューク大学 ( ノースカロライナ州 ) の Kyle Van Houtan と水産関係の専門家であるブ リティッシュ・コロンビア大学（バン クーバー) の Dan Pauly は、Google Earthで入手できる衛星画像で、こう した泥の航跡をたくさん見つけた。メ キシコ湾からマレーシアまでのリモー トセンシング画像には、海上のさまざ まなようすが捕らえられており、1隻 の船がひくトロール網の数もわかるし、 混穫して船外に捨てられる魚をごちそ うになろうと、漁船の周りに群れ飛ぶ 海鳥も白い点として見えている。

今回のこの画像は、2003 年 2 月 20 日に商用衛星クイックバードが長江の河 口付近にある江蘇省沿岸を撮影したも の。10隻のトロール漁船団がそれぞれ
1キロメートル四方をカバーしている。 Van Houtan と Pauly は現在、漁 業が生態系に及ぼす影響を把握するた め、クイックバードや地球観測衛星ラ ンドサットなどの衛星データを使って、 こうした漁船がどれくらいの量の堆積 物をかき混ぜているのかを高精度で割 り出そうと、研究を進めているところ だ。彼らの話では、トロール漁を繰り 返すことで、海底の状態が恒久的に変 化して、この海域の上層にすむ生物た ちの生態系まで変えてしまう可能性が あるという。

「想像も大事だが、画像だってそれに 負けない。1枚の画像を見れば、漁業 の及ぼす影響や海に対する1つの姿勢 を具体的に見ることができるのだから」 とVan Houtanは語った。 